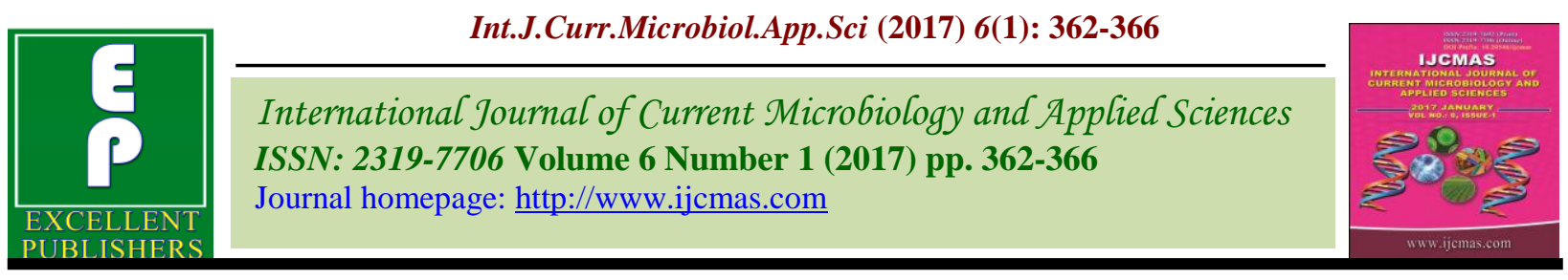

Original Research Article http://dx.doi.org/10.20546/ijcmas.2017.601.043

\title{
Role of Rapid Test and ELISA in the Diagnosis of HCV in Haemodialysis Patients
}

\author{
Kanaga Priya Muthiah ${ }^{1 *}$ and T. Susitha ${ }^{2}$ \\ ${ }^{1}$ Department of Microbiology, Tirunelveli Medical College, Tirunelveli, India \\ ${ }^{2}$ Department of Microbiology, KanyaKumari Government Medical College, Asaripallam, India
}

*Corresponding author

\begin{tabular}{|c|c|}
\hline & A B S T R A C T \\
\hline $\begin{array}{l}\text { K e y w or d s } \\
\text { HCV, ICT, } \\
\text { ELISA, } \\
\text { Haemodialysis, } \\
\text { Chronic Kidney } \\
\text { disease. }\end{array}$ & $\begin{array}{l}\text { The usefulness of Rapid test and ELISA in the diagnosis of HCV in haemodialysis patients } \\
\text { was analysed. In this study, Immuno Chromatography Test [ICT] rapid test was compared } \\
\text { with ELISA for the effective detection of anti-HCV antibodies in patients on } \\
\text { haemodialysis. A total of } 106 \text { blood samples, from chronic renal disease patients on } \\
\text { haemodialysis were taken from the Department of Nephrology, Government Medical } \\
\text { College Hospital, for a period of six months from July to December } 2011 \text {. Sera were tested } \\
\text { for anti HCV antibodies by rapid ICT and further tested by third generation ELISA. Anti- }\end{array}$ \\
\hline Article Info & $\begin{array}{l}\mathrm{HCV} \text { antibodies were positive in } 6(5.66 \%) \text { patients by ICT method while } 7(6.6 \%) \\
\text { patients were positive by ELISA method. The sensitivity and specificity of the ICT kit }\end{array}$ \\
\hline $\begin{array}{l}\text { Accepted: } \\
18 \text { December } 2016 \\
\text { Available Online: } \\
10 \text { January } 2017\end{array}$ & $\begin{array}{l}\text { were } 85.7 \% \text { and } 100 \% \text { respectively whereas positive and negative predictive values were } \\
100 \% \text { and } 99 \% \text { respectively, which were significantly high and quite equivalent to the } \\
\text { ELISA results. An ideal rapid test is a boon in time-saving situations like dialysis. Hence } \\
\text { we conclude that HCV screening can be preferably done by a rapid test followed by a } \\
\text { supplemental ELISA and polymerase chain reaction. }\end{array}$ \\
\hline
\end{tabular}

\section{Introduction}

Infection with Hepatitis $\mathrm{C}$ virus (HCV) has been identified as the major cause of posttransfusion non-A, non-B hepatitis (Capner et al., 2007). The prevalence of $\mathrm{HCV}$ is consistently higher among haemodialysis patients than in general population and has been associated with greater morbidity and mortality (Natov et al., 1996). The high prevalence of $\mathrm{HCV}$ infection in haemodialysis patients has been attributed not only to the frequency of blood transfusion but also to increasing years on dialysis suggesting that $\mathrm{HCV}$ may be transmitted among patients in the dialysis unit, probably as a result of poor infection control practices (Quer et al., 2005).

Laboratory diagnosis of $\mathrm{HCV}$ infection is usually based on the detection of circulating antibodies (Narayan et al., 2001). The Immunochromatographic test (ICT) is rapid and simple and could be used in settings with limited facilities (Batool et al., 2009). Enzyme- linked Immunosorbent Assay (ELISA) is widely used for anti-HCV antibody screening. A confirmatory test like radio-immunoassay or molecular technologies of higher specificity are recommended to test 
all those samples found reactive by the screening test (WHO report, 2001). In this study, ICT is compared with ELISA for the effective detection of anti-HCV antibodies in patients on haemodialysis.

Chronic kidney disease (CKD) was included among Non -Communicable Diseases (NCD) in 2011by World Health Organization. HCV is linked to $\mathrm{CKD}$ in several ways -some forms of renal disease are precipitated by $\mathrm{HCV}$ and ESRD patients are at rising risk of HCV acquisition. Nowadays, the spread of $\mathrm{HCV}$ among dialysis patients is declining but its prevalence remains high mainly in developing countries. Periodic screening of $\mathrm{HCV}$ infection is mandatory to prevent newer transmission and there is a need of effective diagnostic method in high resource regions. With this back-ground, this study entails in demonstrating the efficiency of ICT in comparison with ELISA in detection of HCV.

\section{Materials and Methods}

Sample size: A total of 106 blood samples, from patients on haemodialysis were collected

Place of study: Tirunelveli Medical College Hospital, Tirunelveli, Department of Nephrology.

Period of study: Six months from July to December 2011.

Inclusion criteria: The patients with chronic renal disease on haemodialysis of all age groups were included in the study.

Exclusion criteria: Pregnant women, acute renal failure cases were excluded.

Consent: An informed oral consent and a structured questionnaire were obtained from all patients.

Ethical clearance clearance: Ethical clearance was also obtained from Institutional Ethical Committee.

\section{Collection and transport of specimen}

About 3-5 ml of blood was collected from the patients on haemodialysis and serum was separated by centrifugation. Sera were tested for anti HCV antibodies by rapid ICT immediately (Span Diagnostics Ltd. India). Sera were stored at $-20^{\circ} \mathrm{C}$ and further tested by third generation ELISA (ERBA diagnostics Mannheim GmbH, Germany) as per the manufacturers' instructions.

\section{Results and Discussion}

A total of 106 blood samples from patients on haemodialysis were screened for anti-HCV antibody. Females constituted $31(29.2 \%)$ of the study population whereas $75(70.8 \%)$ were males. Both sexes were maximum in the age group of 40-59 years. The mean ages of males and females were 44.2 years and 41.2 years respectively. The difference of age between the gender was not statistically significant $(\mathrm{P}>0.05)$. (Table1)

Anti-HCV antibodies were positive in 6 (5.66\%) patients by ICT method while 7 (6.6\%) patients were positive by ELISA method. There was no statistical significance between ICT and ELISA methods for HCV detection. All the females were negative by both methods. Remaining 99 samples were negative by both ICT and ELISA methods. Anti - HCV antibodies were negative at extremes of age such as below 20 years and above 60 years. The prevalence of $\mathrm{HCV}$ infection among haemodialysis patients in this study was $6.6 \%$.

In the 20-39 years age group, 4 (14.3\%) were positive by ICT and $5(11.9 \%)$ were positive by ELISA while among 40- 59 years, 2 (5.9\%) were positive by both methods.(Table 
2). The sensitivity and specificity of the ICT kit were $85.7 \%$ and $100 \%$ respectively whereas positive and negative predictive values were $100 \%$ and $99 \%$ respectively. (Table 3)

It is well known that haemodialysis patients are at high risk for development of $\mathrm{HCV}$ infection. The prevalence of $\mathrm{HCV}$ infection varies greatly among various patients on haemodialysis from different geographic regions. However, the data on the prevalence of anti-HCV among Indian haemodialysis patients remains scanty. In the present study, the prevalence of $\mathrm{HCV}$ infection among haemodialysis patients was found to be $6.6 \%$. This is in accordance with (Reddy et al., 2005), where the prevalence of HCV was $5.9 \%$ and (Almari et al., 2005), where the prevalence was $6.1 \%$. This is in contrast to the high prevalence rate by (Telaku et al., 2009), (43\%) and (Bdour et al., 2002) $(34.6 \%)$.

Since the introduction of screening assays for $\mathrm{HCV}$ antibodies, major efforts had been made to increase the diagnostic accuracy of the assays. The major concern in using rapid ICT is their variable degree of sensitivity and specificity. An ideal rapid test would have a high degree of positive predictive value and low degree of false negative result.( Khan et al., 2010). Out of the 106 samples, $6(5.66 \%)$ were detected by the rapid ICT for anti-HCV antibodies. In the present study, ELISA was considered as the gold standard to document $\mathrm{HCV}$ infection. Results of this study showed that the sensitivity of the rapid ICT kit was low $(85.7 \%)$ compared to the specificity $(100 \%)$, positive predictive value $(100 \%)$ and negative predictive value $(99 \%)$ which were significantly high. The results of the study by (Khan et al., 2010) showed that the sensitivity of the rapid test was $45 \%$ only for $\mathrm{HCV}$ detection.
An additional positive sample detected by ELISA for $\mathrm{HCV}$ antibodies in the present study could be due to the short incubation period of the ICT. Characteristically short incubation tests, do not detect low affinity or low concentration of antibodies as compared to the classic type of immunoassays which employ longer incubation time allowing reaction to proceed to completion. (Khan et al., 2010) the study by (Daniel et al., 2005) showed a similar result, where one sample was negative by rapid test among ELISA tested positive samples for HCV detection.

In this study, all the positive samples belonged to male gender. It is thought that females had delayed health seeking behaviour. This is similar to the study by (Khan et al., 2011) where higher prevalence was seen among males but the study by (Hamissi et al., 2011) found almost equal prevalence between males $(8.8 \%)$ and females $(10.5 \%)$.

In the present study, ELISA detected 7 (6.6\%) out of 106 samples for anti-HCV antibodies. Negative serology in spite of HCV viremia has been documented in haemodialysis patients. HCV viremia in the absence of anti$\mathrm{HCV}$ may occur in the viremic stage early in acute infection. The antibody response in chronic haemodialysis tends to be poor and ELISA may underestimate the problem (Mukophadhya, 2008).

It has been documented that among immune compromised populations, the proportion of false positive results with the third generation ELISA averages $15 \%$. Therefore one should not rely exclusively on a positive anti-HCV screening test to determine whether a person is infected with $\mathrm{HCV}$. A positive screening test should be verified with an independent supplemental test like radio-immunoassay or polymerase chain reaction with high specificity (CDC \& P, MMWR report 2003). 
Table.1 Demographic status among haemodialysis patients

\begin{tabular}{|l|c|c|c|c|}
\hline \multirow{2}{*}{ Age group (years) } & \multicolumn{2}{|c|}{ Male } & \multicolumn{2}{c|}{ Female } \\
\cline { 2 - 5 } & No & $\%$ & No & \% \\
\hline Less than 20 & 2 & 2.7 & 2 & 6.5 \\
\hline $20-39$ & 28 & 37.3 & 13 & 41.9 \\
\hline $40-59$ & 34 & 45.3 & 13 & 41.9 \\
\hline 60 and above & 11 & 14.7 & 3 & 9.7 \\
\hline Total & 75 & 100.0 & 31 & 100.0 \\
\hline Mean + S.D & \multicolumn{2}{|c|}{$44.2 \pm 13.8$} & $41.2 \pm 13.9$ \\
\hline Significance & ' $t$ ' $=1.03$ & d.f $=104$ & $p>0.05$ \\
\hline
\end{tabular}

d.f- degrees of freedom

Table.2 Age wise distribution among HCV positives by ICT and ELISA

\begin{tabular}{|l|c|c|c|c|c|c|}
\hline \multirow{2}{*}{ Age group (years)' } & \multicolumn{2}{|c|}{ ICT } & \multicolumn{2}{c|}{ ELISA } & \multirow{2}{*}{$\mathbf{Z}^{\prime}$} & \multirow{2}{*}{ p Value } \\
\cline { 2 - 6 } & Positive & $\mathbf{\%}$ & Positive & $\mathbf{\%}$ & & \\
\hline $20-39(\mathrm{n}=28)$ & 4 & 14.3 & 5 & 17.9 & 0.367 & $\mathrm{p}>0.05$ \\
\hline $40-59(\mathrm{n}=34)$ & 2 & 5.9 & 2 & 5.9 & 0.0 & $\mathrm{p}=1.00$ \\
\hline Total $(\mathrm{n}=62)$ & 6 & 9.7 & 7 & 11.3 & 0.291 & $\mathrm{p}>0.05$ \\
\hline
\end{tabular}

Table.3 Comparison of ICT with ELISA

\begin{tabular}{|l|c|c|c|c|c|}
\hline \multicolumn{2}{|c|}{} & \multicolumn{2}{|c|}{ ELISA n=106 } & $\mathbf{Z}^{2}$ and ${ }_{\chi}{ }^{2}$ & Significance \\
\cline { 3 - 5 } & + & - & & \\
\cline { 1 - 4 } ICT $\mathrm{n}=106$ & + & 6 & 0 & 0.0 & $\mathrm{p}=1.00$ \\
\cline { 2 - 4 } & - & 1 & 99 & & \\
\hline
\end{tabular}

Since immunization against $\mathrm{HCV}$ is not yet available, identification and isolation of infected $\mathrm{HCV}$ patients may minimize its spread in dialysis units.(Weinstein et al., 2001). This study highlights that an ideal rapid ICT is a valuable tool in emergency situations like dialysis. An additional test if available can detect $\mathrm{HCV}$ infection and helps to avoid nosocomial transmission of $\mathrm{HCV}$ infection among patients on haemodialysis with low antibody titre.

In conclusion, in the present study the sensitivity of the rapid ICT was $85.7 \%$ and a $100 \%$ specificity $(100 \%)$, positive predictive value $(100 \%)$ and negative predictive value (99\%) which were significantly high and quite equivalent to the ELISA results. An ideal rapid test is a boon in time-saving situations like dialysis. Since HCV screening by a rapid test is easier, time saving, can be easily performed by any trained heath care worker, at any time of need, it can definitely be preferred as a screening test not only before haemodialysis but also for any other emergency surgery. It is cost effective also. Hence we conclude that HCV screening can be preferably done by a rapid test followed by a supplemental ELISA and polymerase chain reaction.

\section{References}

Almawi, W.Y., Qadi, A.A., Tamim, H., Ameen, G., Bu-Ali, A., Arrayid, S. et al. 2004. Seroprevalence of hepatitis C Virus and 
hepatitis B Virus among dialysis patients in Bahrain and Saudi Arabia. Transplant Proc., 36(6): 1824-26.

Alter, M.J., Kuhnert, W.L., Finelli, L. 2003. Centers for Disease Control and Prevention. Guidelines for laboratory testing and result reporting of antibody to hepatitis C virus. Centers for Disease Control and Prevention. MMWR Recomm. Rep., 52: 1-13.

Batool, A., Khan, M.I., Bano, K.A. 2009. Efficacy of immunoassay chromatography test for hepatitis- $\mathrm{C}$ antibodies detection. $J$. Ayub. Med. Coll. Abbottabad, 21(3): 38-9.

Bdour, S. 2002. Hepatitis C virus infection in Jordanian haemodialysis units: serological diagnosis and genotyping. J. Med. Microbiol., 51(8): 700-4.

Capner, P.M., Simmonds, P., Peutherer, J.F. 2007. Togavirus and hepacivirus. In: Greenwood D, Slack R, Peutherer J, Barer M. editors. Medical microbiology.17th ed. Philadelphia: Chruchill Livingstone; 2007.p.524-35.

Daniel, H.D., Abraham, P., Raghuraman, S., Vivekanandan, P., Subramaniam, T., Sridharan, G. 2005. Evaluation of a rapid assay as an alternative to conventional enzyme Immunoassays for detection of hepatitis C virus-specific antibodies. $J$. Clin. Microbiol., 43(4): 1977-8.

Hamissi, J., Hamissi, H. 2011. Occurence of hepatitis $\mathrm{B}$ and $\mathrm{C}$ infection among haemodialyzed patients with chronic renal failure in Qazvin, Iran: A preliminary study. Int. J. Coll. Res. Internal. Med. Pub. Health, 3(1): 89-96.

Khan, J.K., Lone, D.S., Hameed, A., Munim, M.R., Bhatti, M., Khattak, A.A. et al.
2010. Evaluation of performance of two rapid immunochromatographic tests for detection of hepatitis B surface antigen and anti $\mathrm{HCV}$ antibodies using ELISA tested samples. Annals of King Edward Medical University, 16(1): 84-7.

Khan, S., Attaullah, S., Ali, I., Ayaz, S., Naseemullah, Khan, S.N. et al. 2011. Rising burden of Hepatitis $\mathrm{C}$ virus in haemodialysis patients. Virol. J., 8(1): 438.

Mukhopadhya, A. 2008. Hepatitis $\mathrm{C}$ in India. $J$. Biosci., 33(4): 465-73.

Narayan, S. 2001. Microbes and blood transfusion. Ind. J. Med. Microbiol., 19(3): 119-26.

Natov, S.N., Pereira, B.J. 1996. Hepatitis C in dialysis patients. Adv. Ren. Replace Ther., 3(4): 275-83.

Quer, J., Esteban, J.I. 2005. Epidemiology. In: Thomas H, Lemon S, Zuckerman A. editors. Viral Hepatitis. 3rd ed. Australia: Blackwell publishing; p.407-25.

Reddy, G.A., Dakshinamururthy, K.V., Neelaprasad, P., Gangadhar, T., Lakshmi, V. 2005. Prevalence of $\mathrm{HBV}$ and $\mathrm{HCV}$ dual infection in patients on haemodialysis. Indian J. Med. Microbiol., 23(1): 41-3.

Telaku, S., Fejza, H., Elezi, Y., Bicaj, T. 2009. Hepatitis B and $\mathrm{C}$ in dialysis units in Kosova. Virol. J., 6:72.

Weinstein, T., Tur-Kaspa, R., Chagnac, A., Korzets, A., Ori, Y., Zevin, D. et al. 2001. Hepatitis $\mathrm{C}$ infection in dialysis patients in Israel. Isr. Med. Assoc J., 3(3):174-7.

WHO. 2001. Hepatitis C assays: Operational characteristics (Phase 1). Blood Safety and clinical technology. World Health Organization Geneva Report 1, p.3.

\section{How to cite this article:}

Kanaga Priya Muthiah and Susitha, T. 2017. Role of Rapid Test and ELISA in the Diagnosis of HCV in Haemodialysis Patients. Int.J.Curr.Microbiol.App.Sci. 6(1): 362-366. doi: http://dx.doi.org/10.20546/ijcmas.2017.601.043 